\title{
INCREASED YIELD AND NUTRITIONAL VALUE OF KUMPAI GRASS (Hymenachne amplexicaulis (Rudge) Nees.) WITH ARBUSCULAR MYCORRHIZAL FUNGI AND ORGANIC FERTILIZER IN RED-YELLOW PODZOLIC SOIL
}

\author{
Hardi Syafria ${ }^{*}$, Novirman Jamarun ${ }^{2}$, Mardiati Zein ${ }^{2}$ and Evita Yani ${ }^{2}$ \\ ${ }^{1}$ Faculty of Animal Science, University of Jambi, Jambi \\ ${ }^{2}$ Faculty of Animal Science, University of Andalas, Padang
}

*Corresponding author : hardisyafria@gmail.com

Received : 5 April 2015

Accepted : 24 November 2015

\begin{abstract}
Arbuscular Mycorrhizal Fungi (AMF) can help plants by improving the uptake of low P availability acid soils. Organic fertilizers can effect the physical, chemical and biological soil. The purpose of this research is to study and determine the effect of AMF and organic fertilizer on increasing yield and nutritional value of kumpai grass in red-yellow podzolic acid soils. The study design used a completely randomized $5 \times 3$ factorial pattern and repeat three times. Two factors as treatment: AMF and organic fertilizer. AMF usage consisted of three levels: control ( $0 \mathrm{~g} /$ pot $)$, AMF (10 g/pot) and AMF $(20 \mathrm{~g} /$ pot $)$. The organic fertilizer usage consisteds of five levels: control $(0 \%)$, manure $(50 \%)$, manure $(100 \%)$, compost $(50 \%)$ and compost $(100 \%)$. Variables measured included the width of leaves, plant length, number of tillers, the yield of forage dry matter, crude protein, phosphorus, dry matter and organic matter digestibility. The results showed that the AMF and organic fertilizer had a highly significant $(\mathrm{P}<0.01)$ effect for all observed variables. The interaction AMF and organic fertilizers had significant effect on crude protein, phosphorus and organic matter digestibility.
\end{abstract}

Keywords: Hymenache amplexicaulis (Rudge) Nees., Arbuscular Mycorrhizal Fungi, Organic Fetilizer, Yield, Nutritive Value.

\section{INTRODUCTION}

Diversification of forage material is needed, to support the needs of foraging on local resources by ruminants. Several types of local forage grasses showed advantages over introduced species. One such example is the local kumpai grass (Hymenachne amplexicaulis (Rudge) Ness.). Kumpai grass has a high biological value that generates a quality foraging material. The protein content $( \pm 11.20 \%)$ is higher than the crude protein elephant grass $(9-10 \%)$. Syafria (2009) stated that the results of forage dry matter and crude protein content of grasses were highest for kumpai obtained on treatments without flooding, fertilizing $300 \mathrm{~kg} \mathrm{~N} /$ ha with an interval cutting every 40 days.

The availability of land for planting forage is reducing because arable land is used for growing food crops, plantations and other non-agricultural purposes. Recent efforts have focused on maximizing forage material from marginal land (Sumarsono, 2006; Anny Mulyani and Irsal Lubis, 2008; Evitayani et al., 2012; Jamarun and Mardiati Zein, 2012).

The area of marginal red-yellow podzolic land in Indonesia \pm 51 million hectares, spread across Borneo, Sumatera, Sulawesi, Irian Jaya and Java (Rachim et al., 2000). In Jambi this marginal land extends $\pm 2,272,725$ ha (44.56 \%) of the area of Jambi Province (Department of Agriculture Jambi Province, 2005). In acidic soils, the nutrient availability and low organic matter content, are vulnerable to erosion, and have the ability to withstand low water (Mengel and Kirkby, 2001). Utilizing this land as a plant growing medium means improving the productivity beforehand, ofespecially certain macro and micro essential nutrients that may be in short supply (Elza Zuhry and Fifi Puspita, 2008; Anny Mulyani and Irsal Las, 2008). Using large quantities of chemical fertilizer can enhance plant growth, but the production system requires high cost inputs and there are long-term negative impacts on the environment (Sukarmin and G. Fatria, 2011). 
According to Eti Farda Husin et al. (2012) the availability of phosphate in acid soils is also one of the limiting factors in increasing crop productivity. Attempts to overcome these problems include the use of AMF and organic fertilizers. The addition of organic matter serves as a slow-release fertilizer that can support plant growth during the AMF is not functioning. AMF infect the host plant root system with interwoven hyphae intensive form, so that the plant is able to increase the absorption of nutrients and water. This increase is not only for macro nutrients but also micro elements. Most important is the nutrient phosphate and when plants have mycorrhizal infection they are able to produce a phosphatase enzyme that works to increase the availability of soil phosphate (Beinroth, 2001). While organic fertilizer has a complete nutrient content, even there are also other organic compounds that are beneficial to plants, such as humic acid, fulfat acids and other organic compounds but there is content is low (Sumarsono et al., 2005). Organic fertilizers can improve soil structure and help the development of soil microorganisms, this is the beginning of a process of transformation of $\mathrm{N}$ in the soil biologically, and results in a conversion of organic $\mathrm{N}$ forms into inorganic forms available to plants (Widjayanto et al., 2001).

Based on the above framework, the purpose of this research is to study and determine the effect of AMF and organic fertilizers as well as its interaction with increased yield and nutritive value of kumpai grass in red-yellow podzolic soils.

\section{MATERIALS AND METHODS}

\section{Materials}

Research was conducted in the village district of New Town Chart Pete Jambi City, Laboratory of Animal Nutrition and Feed Faculty of Animal Science, University of Jambi, Laboratory of Soil Science, Faculty of Agriculture, University of Andalas, Laboratory of Plant Biology, University of Andalas, Ruminant Nutrition Laboratory, and Non-Ruminant Nutrition Laboratory of the Faculty of Animal Science, University of Andalas. The study lasted for five months, starting in February and ending in June 2014.

Kumpai grass (Hymenachne amplexicaulis (Rudge) Nees.) was used as the research material. This grass comes from Talang Duku Muaro Jambi, Jambi Province. The AMF used included multiple types of spores with trademark Cemiko I consisting of (Glomus sp, Akoulus sp and Skutelo sp) obtained from the Laboratory of Soil Department, Faculty of Agriculture, University of Andalas. Organic fertilizer used was cow dung manure and compost. As the base used TSP fertilizer $\left(150 \mathrm{~kg} \mathrm{P}_{2} \mathrm{O}_{5} / \mathrm{ha}\right) ; \mathrm{KCl}$ $(100 \mathrm{~kg} \mathrm{~K} 2 \mathrm{O} / \mathrm{ha}) ; \mathrm{CO}\left(\mathrm{NH}_{2}\right)_{2}(200 \mathrm{~kg} \mathrm{~N} / \mathrm{ha})$; and $\mathrm{C}_{\mathrm{a}} \mathrm{CO}_{3}(2 \mathrm{ton} / \mathrm{ha})$ For the planting medium we used acidic red-yellow podzolic soil. The equipment used was earth moving equipment, bar, sprinklers, plastic bags, scales, measuring $10 \mathrm{~kg}$ poly bags, and laboratory equipment for the analysis of the nutritional value of forage.

\section{Methods}

The experimental method used a completely randomized design (CRD) $5 \times 3$ factorial design, two factors as treatment, AMF and organic fertilizer. AMF $(0 \mathrm{~g} /$ pot, $10 \mathrm{~g} / \mathrm{pot}$, and $20 \mathrm{~g} / \mathrm{pot})$; Organic fertilizers: control (0\%), manure (50\%), manure (100\%), compost $(50 \%)$, compost $(100 \%)$. Thus there are 15 combinations of treatments, repeated three times, so 45 experimental units in total, each of which consists of two pots; In total 90 pots were used. Variables measured the width of the leaf, plant length, number of tillers, the yields of forage dry matter, crude protein, phosphorus, dry matter and organic matter digestibility.

\section{Implementation}

Soil to be used as a planting medium was cleaned of rocks, roots and gravel rest before dries aired. Planting medium for each experiment were placed in a pot to a depth of $20 \mathrm{~cm}$ with a weight of $7 \mathrm{~kg}$ dry weight soil air. Basic fertilizer TSP, $\mathrm{KCl}, \mathrm{CO}\left(\mathrm{NH}_{2}\right)_{2}$, and $\mathrm{C}_{\mathrm{a}} \mathrm{CO}_{3}$ and organic fertilizers used as treatments were given simultaneously, by mixing with the soil in the pot. An AMF inoculum was given by inserting inoculum into each planting hole, done in conjunction with the planting of grass. The grass 
planting material was in the form of stems (cuttings) which consists of three cutting /pot.

Maintenance was carried out by watering with water, controlling weeds, pests and diseases. Observations were made every eight days. The results of forage dry matter, crude protein, phosphorus, dry matter and organic matter digestibility were observed after the plant was cut. Cutting was done twice with an interval of 40 days cutting. Statistical data processing was done using a completely randomized design; analysis of variance used to determine the effect of treatments and their interactions. Significance was tested with Duncan's multiple range test.

\section{RESULTS AND DISCUSSION}

\section{Width of leaves, Plants Length, Number of Tillers and Yield of Dry Matter Forage}

Results of analysis of variance showed that the AMF and organic fertilizers demonstrated a significant effect on leaf width, plant length, number of tillers and yield of dry matter forage, while the interaction did not show any significant. The average values of the observations are listed in Table 1.

Table 1. Effect of AMF and Organic Fertilizer to Width of Leaves (WL), Plants Length (PL), Number of Tillers (NL) and Yield of Dry Matter Forage(YDMF).

\begin{tabular}{|c|c|c|c|c|c|}
\hline Treatment & & $\begin{array}{c}\mathrm{WL} \\
\text { (cm/pot) }\end{array}$ & $\begin{array}{c}\mathrm{PL} \\
\text { (cm/pot) }\end{array}$ & $\begin{array}{c}\mathrm{NL} \\
\text { (stem/pot) }\end{array}$ & $\begin{array}{l}\text { YDMF } \\
\text { (g/pot) }\end{array}$ \\
\hline \multicolumn{6}{|l|}{ Cutting I: } \\
\hline \multicolumn{6}{|l|}{ AMF: } \\
\hline $10 \mathrm{~g} / \mathrm{pot}$ & & $\begin{array}{l}1.05 \mathrm{~d} \\
1.78 \mathrm{~b}\end{array}$ & $91.50 \mathrm{~b}$ & $35.80 \mathrm{~b}$ & $72.40 \mathrm{~b}$ \\
\hline $20 \mathrm{~g} / \mathrm{pot}$ & & $1.80 \mathrm{~b}$ & $98.25 \mathrm{c}$ & $42.50 \mathrm{c}$ & $82.20 \mathrm{c}$ \\
\hline \multicolumn{6}{|c|}{ Organic Fertilizer: } \\
\hline Controls & : $\quad 0 \%$ & $1.30 \mathrm{a}$ & $65.24 \mathrm{a}$ & $22.90 \mathrm{a}$ & $47.57 \mathrm{a}$ \\
\hline Manure & : $50 \%$ & $1.50 \mathrm{~b}$ & $74.25 \mathrm{c}$ & $28.20 \mathrm{c}$ & $67.75 \mathrm{c}$ \\
\hline Manure & $: 100 \%$ & $1.75 \mathrm{c}$ & $86.55 \mathrm{e}$ & $38.50 \mathrm{e}$ & $75.55 \mathrm{e}$ \\
\hline Compost & : $50 \%$ & $1.45 \mathrm{~b}$ & $71.20 \mathrm{~b}$ & $25.72 b$ & $60.80 \mathrm{~b}$ \\
\hline Compost & $: 100 \%$ & $1.70 \mathrm{c}$ & $78.80 \mathrm{~d}$ & $32.61 \mathrm{~d}$ & $70.50 \mathrm{~d}$ \\
\hline \multicolumn{6}{|l|}{ Cutting II: } \\
\hline \multicolumn{6}{|l|}{ AMF: } \\
\hline $0 \mathrm{~g} / \mathrm{pot}$ & & $1.68 \mathrm{a}$ & $83.40 \mathrm{a}$ & $25,40 \mathrm{a}$ & $60.48 \mathrm{a}$ \\
\hline $10 \mathrm{~g} / \mathrm{pot}$ & & $1.84 \mathrm{~b}$ & $95.20 \mathrm{~b}$ & $40.25 \mathrm{~b}$ & $80.45 \mathrm{~b}$ \\
\hline $20 \mathrm{~g} / \mathrm{pot}$ & & $1.90 \mathrm{~b}$ & $105.20 \mathrm{c}$ & $50.30 \mathrm{c}$ & $88.50 \mathrm{c}$ \\
\hline \multicolumn{6}{|l|}{ Organik Fertilizer: } \\
\hline Controls & $: \quad 0 \%$ & $1.40 \mathrm{a}$ & $85.50 \mathrm{a}$ & $28.11 \mathrm{a}$ & $50.30 \mathrm{a}$ \\
\hline Manure & : $50 \%$ & $1.70 \mathrm{~b}$ & $93.50 \mathrm{c}$ & $37.60 \mathrm{c}$ & $73.80 \mathrm{c}$ \\
\hline Manure & $: 100 \%$ & $1.85 \mathrm{c}$ & $99.50 \mathrm{e}$ & $42.50 \mathrm{e}$ & $80.75 \mathrm{e}$ \\
\hline Compost & : $50 \%$ & $1.65 \mathrm{~b}$ & $90.75 \mathrm{~b}$ & $34.40 \mathrm{~b}$ & $68.05 \mathrm{~b}$ \\
\hline Compost & $: 100 \%$ & $1.80 \mathrm{c}$ & $96.40 \mathrm{~d}$ & $38.40 \mathrm{~d}$ & $77.56 \mathrm{~d}$ \\
\hline
\end{tabular}

Description: The average value followed by different lowercase letters in the same column indicate significant difference at $5 \%$ level by Duncan's multiple range test.

In the first and second cutting, AMF treatment $20 \mathrm{~g} /$ pot resulted in higher leaf width $(\mathrm{P}>0.05)$ compared with $10 \mathrm{~g} /$ pot and significantly different from $0 \mathrm{~g} /$ pot. Furthermore AMF $10 \mathrm{~g} /$ pot yield was higher $(\mathrm{P}<0.05)$ compared with $0 \mathrm{~g} /$ pot. The length of the plant, number of tillers, and the results of dry matter forage on AMF $20 \mathrm{~g} /$ pot also showed the highest yield $(\mathrm{P}<0.05)$ compared to $10 \mathrm{~g} /$ pot and $0 \mathrm{~g} / \mathrm{pot}$, as well as AMF $10 \mathrm{~g} /$ pot than $0 \mathrm{~g} /$ pot. 
AMF treatment $10 \mathrm{~g} /$ pot on the first and second cutting increased the width of leaves $(9.20 \%$ and $9.50 \%)$, length of the plant $(13.95 \%$ and $14.15 \%)$, number of tillers $(54.31 \%$ and $58.47 \%)$, and the yield of forage dry matter $(24.04 \%$ and $33.02 \%)$, while the AMF $20 \mathrm{~g} /$ pot increased leaf width (10.43 $\%$ and $13.10 \%$ ), the length of the plant $(22.35 \%$ and $26.14 \%)$, the number of seedlings $(83.15 \%$ and $98.03 \%$ ), and the results of material dry forage ( $40.83 \%$ and $46.33 \%$ ) compared to the AMF $0 \mathrm{~g} / \mathrm{pot}$.

Higher yield from the AMF treatment were, due to AMF improving soil structure and increasing the absorption of nutrients from the soil; by increasing nutrient uptake; photosynthesis will then increase so more carbohydrate produced by plants that will be used for the establishment of vegetative parts of plants. (Beinroth, 2001) states that AMF can increase the absorption of nutrients and water from the soil, which will allow the plant to produce new cells and growth hormones which will then be able to increase the growth of the vegetative part of the plant. According to Eti Farda Husin et al. (2012) hyphae (mycelium) AMF can improve plant nutrition and produce growth hormones such as auxin and gibberellin. Auxin prevents aging of the roots, so their nutrient absorption function is maintained, while gibberellins serves to stimulate cell division, especially enlargement and primary cells. Kanno et al., (2006) showed that the administration of AMF may increase the growth and production of tropical forage fodder. Karti (2004) demonstrated that AMF administration may increase the growth and production of grass Setaria splendida Stapf. experiencing drought. Vera Nania (2007) showed that the administration of AMF on saline soils can increase the growth and production of grass Chloris gayana Kunt, with the highest results obtained in the provision of mycorrhizal $20 \mathrm{~g} / \mathrm{pot}$ and $840 \mathrm{~kg} \mathrm{NPK} / \mathrm{ha}$. Karti (2004) and Setiadi (2011) showed that AMF is able to increase the growth and production of grass Chloris gayana on acid soils with high aluminum.

The treatment of manure $100 \%$ yielded the highest leaf length and leaf width $(\mathrm{P}>0.05)$ compared to compost $100 \%$, which was significantly different from $50 \%$ compost, manure $50 \%$ and $0 \%$; compost $100 \%$ yield was higher $(\mathrm{P}<0.05)$ compared with $50 \%$ compost, manure $50 \%$ and $0 \%$; compost $50 \%$ yield was higher $(\mathrm{P}>0.05)$ compared to $50 \%$ manure and significantly different from 0 $\%$. Furthermore, the treatment using manure $100 \%$ yielded a crop length, number of tillers and the highest forage dry matter $(\mathrm{P}<0.05)$ compared to compost $100 \%, 50 \%$ manure, compost $50 \%$ and $0 \%$; the compost $100 \%$ yield was higher $(\mathrm{P}<0.05)$ compared to $50 \%$ of manure, compost $50 \%$ and $0 \%$. Similiarly animal manure compost $100 \%$ was higher compared to $50 \%$ and $0 \%$, and $50 \%$ compost than $0 \%$.

Forage dry matter yield increase highest in the first and second cuts obtained from manure treatment $100 \%$ (58.82\% and $60.54 \%$ ), followed by compost $100 \%$ (48.20\% and $54.20 \%$ ), manure $50 \%$ (42.42\% and $46.72 \%)$, compost $50 \%(27.81 \%$ and $35.29 \%)$ compared to $0 \%$.

The addition of organic fertilizer increases production of forage dry matter higher. Dry matter yield forage increase aligned with the addition of organic fertilizer dose level. Organic fertilizer, will increase the nutrient content, improved physical, chemical and biological properties of the soil, maintain and improve soil fertility, thus increasing agriculture productivity. Hardjowigeno (2003) stated that the addition of organic matter into the soil provides, a source of nutrients, micro fastener elements and cations, increasing the cation exchange capacity, $\mathrm{pH}$, organic $\mathrm{C}$ and increasing the availability of phosphorus. Irwan et al. (2004) stated that the organic fertilizer of cow manure can increase growth and yield of sorghum (Sorghum bicolor (Linn) Moench.). Apong Sandrawati et al. (2007) demonstrated that the addition of cow manure and compost had a positive influence on the improvement of productivity of maize crops in the ground Fluventic Eutrudepts.

\section{Crude Protein, Phosphorus, Dry Matter and Organic Matter Digestibility.}

Results of analysis of variance showed that the AMF and organic fertilizers had a significant effect on crude protein, phosphorus, dry matter and organic matter digestibility of forage. While the interaction between AMF and organic fertilizers had no significant effect on crude protein, phosphorus and organic matter digestibility. The average value of the observations are listed in Tables 2 and 3. 
In Table 2., the treatment AMF $20 \mathrm{~g} /$ pot produces crude protein, phosphorus, dry matter and organic matter digestibility highest $(\mathrm{P}<0.05)$ compared to $10 \mathrm{~g} /$ pot and $0 \mathrm{~g} /$ pot, then AMF $10 \mathrm{~g} / \mathrm{pot}$ result is higher $(\mathrm{P}<0.05)$ compared with $0 \mathrm{~g} /$ pot. For organic fertilizers, manure treatment resulted in $100 \%$ crude protein, phosphorus, dry matter and organic matter digestibility highest $(\mathrm{P}<0.05)$ compared to compost $100 \%, 50 \%$ manure, compost $50 \%$ and $0 \%$; compost $100 \%$ yield was higher (P $<0.05)$ compared to $50 \%$ of manure, compost $50 \%$ and $0 \%$; manure $50 \%$ higher $(\mathrm{P}<0.05)$ compared to compost $50 \%$ and $0 \%$; and compost $50 \%$ higher $(\mathrm{P}<0.05)$ compared to $0 \%$.

Table 2. Effect of AMF and Organic Fertilizer to Crude Protein (CP), Phosphorus (P), Dry Matter (DMD) and Organic Matter Digestibility (OMD).

\begin{tabular}{cccccc}
\hline Treatment & & $\begin{array}{c}\text { CP } \\
(\%)\end{array}$ & $\begin{array}{c}\text { P } \\
(\%)\end{array}$ & $\begin{array}{c}\text { DMD } \\
(\%)\end{array}$ & $\begin{array}{c}\text { OMD } \\
(\%)\end{array}$ \\
\hline AMF: & & & & & \\
$0 \mathrm{~g} /$ pot & & $13.10 \mathrm{a}$ & $0.85 \mathrm{a}$ & $48.75 \mathrm{a}$ & $50.20 \mathrm{a}$ \\
$10 \mathrm{~g} /$ pot & & $16.35 \mathrm{~b}$ & $1.20 \mathrm{~b}$ & $62.40 \mathrm{~b}$ & $65.25 \mathrm{~b}$ \\
$20 \mathrm{~g} /$ pot & & $17.50 \mathrm{c}$ & $1.60 \mathrm{c}$ & $66.50 \mathrm{c}$ & $68.40 \mathrm{c}$ \\
Crganic Fertilizer: & & & & \\
Controls $: 0 \%$ & $13.25 \mathrm{a}$ & $0.65 \mathrm{a}$ & $50.10 \mathrm{a}$ & $52.15 \mathrm{a}$ \\
Manure $: 50 \%$ & $15.60 \mathrm{c}$ & $0.97 \mathrm{c}$ & $61.63 \mathrm{c}$ & $63.75 \mathrm{c}$ \\
Manure $: 100 \%$ & $17.15 \mathrm{e}$ & $1.25 \mathrm{e}$ & $66.90 \mathrm{e}$ & $68.20 \mathrm{e}$ \\
Compost $: 50 \%$ & $14.45 \mathrm{~b}$ & $0.78 \mathrm{~b}$ & $57.50 \mathrm{~b}$ & $60.20 \mathrm{~b}$ \\
Compost $: 100 \%$ & $16.15 \mathrm{~d}$ & $1.18 \mathrm{~d}$ & $64.26 \mathrm{~d}$ & $65.85 \mathrm{~d}$ \\
\hline
\end{tabular}

Description: The average value followed by different lowercase letters in the same column indicate significant difference at $5 \%$ level by Duncan's multiple range test.

AMF treatment $10 \mathrm{~g} /$ pot and $20 \mathrm{~g} /$ pot can increase crude protein $(24.81 \%$ and $33.59 \%)$ ), phosphorus ( $41.18 \%$ and $88.24 \%$ ), dry matter digestibility $(28.00 \%$ and $36.41 \%$ ) and organic matter digestibility ( $29.98 \%$ and $36.26 \%$ ) compared to the AMF $0 \mathrm{~g} /$ pot. Furthermore, the AMF treatment 20 $\mathrm{g} /$ pot can increase crude protein $(7.03 \%)$, phosphorus $(33.33 \%)$, dry matter digestibility $(6,57 \%)$ and organic matter digestibility ( $4.83 \%$ ) when compared to the AMF $10 \mathrm{~g} /$ pot.

The increased nutritional value of kumpai grass from the AMF treatment was; due to the hyphae of AMF being associated with the roots, causing the plant to absorb more nutrients in the soil and absorbing water from the soil pores when plant can no longer absorb water. This is; because the water absorption by hyphae in the soil is very broad so that the plant can get more water. This was was evidenced by good root system development, reflected by higher root dry weight in plants that are subjected to the AMF. Symbiotic mutualism occurs because mycorrhizal fungi living in the root cells get most of the carbon from the process of photosynthesis of plants, and the plants get the nutrients and water or other benefits of mycorrhizal fungi. AMF serves to increase the absorption of nutrients from the soil, plants with mycorrhizal fungi generally grow better than without mycorrhiza, and can effectively improve the absorption of nutrients such as $\mathrm{N}, \mathrm{P}, \mathrm{K}$ and $\mathrm{Mg}$. Increasing absorption of nutrients will have a positive impact on the growth of both the vegetative part and the nutritional value of forage material.

In the treatment of organic fertilizer, the highest increase in forage nutritive value of manure was obtained at $100 \%$, with crude protein $(29.43 \%)$, phosphorus $(92.30 \%)$, dry matter digestibility $(33.53$ $\%$ ) and organic matter digestibility (30.78\%). The second highest treatment was compost $100 \%$, with crude protein $(21.89 \%)$, phosphorus $(81.5 \%)$, dry matter digestibility $(28.26 \%)$ and organic matter digestibility $(26.27 \%)$. The next highest increase was manure $50 \%$, with crude protein $(17.74 \%)$, phosphorus $(49.23 \%)$, dry matter digestibility $(23.01 \%)$ and organic matter digestibility $(22,24 \%)$. This was followed by compost $50 \%$, with crude protein $(9.06 \%)$, phosphorus $(1.54 \%)$, dry matter digestibility $(14.77 \%)$ and organic matter digestibility $(15,44 \%)$ than without organic fertilizer. 
Organic fertilizer produce forage nutritional value higher than without organic fertilizers with, the increase in line with the organic fertilizer dose level. Simanungkalit et al. (2006) found that organic fertilizers or soil organic matter is a major source of soil nitrogen and has, a large role improving the physical, chemical and biological soil and the environment. Organic fertilizers added to the soil will in times be overhauled by soil microorganisms to become humus or soil organic matter. So organic fertilizer are very beneficial for increasing crop productivity in both quantity and quality.

The effect of the interaction of the AMF and organic fertilizers on the content of crude protein, phosphorus and organic matter digestibility (|Table 3.), showed that the combined treatment of AMF 20 $\mathrm{g} /$ pot with manure $100 \%$ yield crude protein, phosphorus and organic matter digestibility was highest, although not significantly different AMF $20 \mathrm{~g}$ /pot with compost $100 \%$, AMF $10 \mathrm{~g} /$ pot with manure 100 $\%$ and AMF $10 \mathrm{~g} /$ pot with compost $100 \%$, but significantly different compared to the other treatment combinations.

Table 3. Effect of AMF Interactions and Organic Fertilizer to Crude Protein (CP), Phosphorus (P), and Organic Matter Digestibility (OMD).

\begin{tabular}{|c|c|c|c|c|c|}
\hline Treatment & & & $\begin{array}{l}\mathrm{CP} \\
(\%) \\
\end{array}$ & $\begin{array}{c}\mathrm{P} \\
(\%) \\
\end{array}$ & $\begin{array}{c}\text { OMD } \\
(\%)\end{array}$ \\
\hline \multirow{3}{*}{ AMF: } & \multicolumn{5}{|c|}{ Organic Fertilizer: } \\
\hline & Controls & $: \quad 0 \%$ & $12.23 \mathrm{e}$ & $0.50 \mathrm{~h}$ & $57.10 \mathrm{e}$ \\
\hline & Manure & : $50 \%$ & $13.25 \mathrm{~d}$ & $0.73 \mathrm{f}$ & $60.02 \mathrm{~d}$ \\
\hline \multicolumn{6}{|l|}{$\%$} \\
\hline \multirow[t]{2}{*}{$0 \mathrm{~g} /$ pot } & Manure & $: 100 \%$ & $14.55 \mathrm{c}$ & $0.87 \mathrm{de}$ & $64.95 \mathrm{~b}$ \\
\hline & Compot & : $50 \%$ & $13.10 \mathrm{~d}$ & $0.67 \mathrm{~d}$ & $58.70 \mathrm{~d}$ \\
\hline 70 & Compost & $: 100 \%$ & $14.30 \mathrm{c}$ & $0.80 \mathrm{c}$ & $63.73 \mathrm{~b}$ \\
\hline \multirow{5}{*}{$10 \mathrm{~g} / \mathrm{pot}$} & Controls & : $0 \%$ & $13.74 \mathrm{~cd}$ & $0.57 \mathrm{~h}$ & $61.20 \mathrm{c}$ \\
\hline & Manure & : $50 \%$ & $15.13 \mathrm{~b}$ & $1.25 \mathrm{bc}$ & $62.21 \mathrm{c}$ \\
\hline & Manure & $: 100 \%$ & $16.36 \mathrm{a}$ & $1.47 \mathrm{a}$ & $68.26 \mathrm{a}$ \\
\hline & Compost & : $50 \%$ & $14.72 \mathrm{bc}$ & $0.81 \mathrm{~d}$ & $61.84 \mathrm{~d}$ \\
\hline & Compost & $: 100 \%$ & $15.85 \mathrm{ab}$ & $1.42 \mathrm{a}$ & $67.81 \mathrm{ab}$ \\
\hline & Controls & : $\quad 0 \%$ & $14.23 \mathrm{c}$ & $0.62 \mathrm{f}$ & $61.35 \mathrm{~d}$ \\
\hline & Manure & : $50 \%$ & $15.47 \mathrm{~b}$ & $1.30 \mathrm{~b}$ & $65.31 \mathrm{~b}$ \\
\hline$\%$ & & & & & \\
\hline \multirow{3}{*}{$\begin{array}{l}20 \mathrm{~g} / \mathrm{pot} \\
\%\end{array}$} & Manure & $: 100 \%$ & $17.13 \mathrm{a}$ & $1.49 \mathrm{a}$ & $69.56 \mathrm{a}$ \\
\hline & Compost & : $50 \%$ & $15.10 \mathrm{~b}$ & $0.85 \mathrm{c}$ & $62.40 \mathrm{c}$ \\
\hline & Compost & $: 100 \%$ & $16.38 \mathrm{a}$ & $1.45 \mathrm{a}$ & $68.96 \mathrm{a}$ \\
\hline
\end{tabular}

Description: The average value followed by different lowercase letters in the same column indicate significant difference at $5 \%$ level by Duncan's multiple range test.

The highest increase in crude protein, phosphorus and organic matter digestibility was obtained by administering AMF. This is because AMF can infect the host plant root system with interwoven hyphae intensive form, which causes the plants to increase the absorption of nutrients, water, and particular phosphate. Absorption of phosphate is important because the low availability of phosphate in acid soils is one of the limiting factors in increasing productivity plant (Eti Farda Husin et al., 2012). According Beinroth (2001) mycorrhizal infection in plants can produce phosphatase enzyme that works to increase the availability of low phosphate availability in acid soils. In addition, the AMF also serves to improve soil structure that allows plant roots to grow and function properly, this condition causes more nutrients can be absorbed by plants, and will result in increased photosynthesis becomes 
more carbohydrates for the establishment and development of the vegetative parts of the plant, so that eventually will give good results on forage nutritive value.

Organic fertilizer is an indispensable source of organic matter for the development of mycorrhiza, since AMF as biofertilizer requires appropriate environmental conditions to optimize its development. Utomo (1995) in Vera Nania (2007) stated that in addition to soil $\mathrm{pH}$, soil conditions affecting the development of mycorrhizal include the availability of organic matter and nutrient availability. From this study it can be argued that increasing the provision of AMF and organic fertilizer; will provide an increase in the content of protein, phosphorus and organic matter digestibility of forage material. Organic fertilizer can also help the development of soil microorganisms which, is the beginning of the process of transformation of organic $\mathrm{N}$ forms into inorganic forms available to plants (Widjayanto et al., 2001), thus providing benefits to the nutritional value of kumpai grass.

\section{CONCLUSION}

AMF and organic fertilizers treatments have a significant effect on leaf width, plant length, number of tillers, the results of dry matter, crude protein, phosphorus, dry matter and organic matter digestibility of forage kumpai grass, while the AMF and organic fertilizer interaction was highly significant for crude protein, phosphorus and organic matter digestibility.

Results of the dry ingredients and the highest forage nutritive value obtained in the treatment of AMF were in the $20 \mathrm{~g} /$ pot, whereas for organic fertilizer obtained in the treatment of manure $100 \%$.

Combination treatment of AMF $20 \mathrm{~g}$ /pot with manure $100 \%$ yield, crude protein, phosphorus and organic matter digestibility which was high although not significantly different from the combination of the AMF $20 \mathrm{~g} /$ pot with compost $100 \%$, AMF $10 \mathrm{~g} /$ pot with manure $100 \%$ as well as combinations of AMF 10/pot with compost $100 \%$, but significantly different compared to the other treatment combination.

The results of the dry ingredients and nutritional value of kumpai grass increased in line with the improvement of the standard dose of AMF and organic fertilizer.

\section{REFERENCES}

Anny Mulyani and Irsal Las. 2008. Potential of Land Resources and Optimization of Commodity Producing Bioenergy Development in Indonesia.

Apong Sandrawati, Emma Trinurani Sofyan and Oviyanti Mulyani. 2007. Effect of Municipal Solid Waste Compost and Cow Manure on Soil Chemical Properties and Yield of Sweet Corn (Zea mays saccharata) in Fluventic Eutrudepts Origin Jatinangor Sumedang District.

Beinroth, F.H. 2001. Land Resources for Forage Production in the Tropics In Sotomayor - Rios A. Pitman Wd (eds) Tropical Forage Plants Development and Use CRC Press.P:3-15.

Department of Agriculture Jambi Province. 2005. Development of Food Crops in Jambi. Jambi.

Elza Zuhry and Fifi Puspita. 2008. Provision of AMF In the Land of Red Yellow Podzolik on Growth and Production of Soybean (Glycine max (L) Merrill). SAGO Scientific Magazine, Vol. 7. No: 2: 25-29. ISSN: 1412-4414.

Evitayani, A. Fariani, L. warly, Suyitman, S. Yani and Emikasmira. 2012. Effect of Dose fertilizer N, P, and $\mathrm{K}$ on In Vitro elephant grass (Pennisetum purpureum) cv. Inoculation Taiwan in AMF Glomus manihotis pada Former Coal Mine Land. Journal of Animal Husbandry Indonesia. Vol.14 (I): 279-285.

Eti Farda Husin, A. Sharif and Kasli. 2012. Mycorrhizae as System Supporting Sustainable Agriculture and Environmental. Andalas University Press.

Hardjowigeno, S. 2003. Soil Science. New Edition. Akademika Pressindo. Jakarta.

A.W. Irwan, A.Wahyudin, R.Susilawati and T. Nurmala. 2005. Interaction of Plant Spacing and Type Manure on Yield Components and levels of sorghum flour (Sorghum bicolor (Linn.) Moench.) On inceptisol in Jatinamgor. 
Jamarun, N. and Mardiati Zain. Basic 2012. Ruminant Nutrition. Publisher Services Solar Padang.

Kanno, T., M. Saito, Y. Ando, M. Congregation of the Mission Macedo, T. Nakamura and C.H.B. Miranda. 2006. Importance of indigenous AMF for growth and phosphourus uptake in tropical forage grasses growing on an acid soil, infertile soil from the Brazilian savannas. Trop. Grasslands. 40:94-101.

Karti, P.D.M.H. 2004. Effect of AMF on the Growth and Production of grass Setaria splendida Stapf. Experiencing Drought Stress. Media Ranch (27): 63-68.

Karti, P.D.M.H and Y. Setiadi. 2011. Response Growth, Production and Quality Grass against AMF and the addition of Humic Acid in Acid Soil with High Aluminum. JITV 16 (2): 104-111.

Mengel, K., and Kirkby, E.A. 2001. Principles of plant nutrition.5th ed., Kluwer Academic Publishers, Dordrecht.

Musfal, 2010. Potential AMF for Improving Crop Corn. Agricultural Research Center for North Sumatra, Medan.

Widya Nasih Yuwono. 2009. Developing Marginal Soil Fertility. Journal of Soil and Environmental Sciences Vol, 2 (2009) p: 137-141.

Rachim, A. R., and A. Hartono Situmorang. 2000. The concept of Sustainable Agricultural Development in the Swamp Land to Support Food Security and Agricultural Development.

Rica Mega Sari. 2012. Production and Nutritional Value elephant grass (Pennisetum purpureum CV.Taiwan) were given a dose of fertilizer N, P, K and AMF Unlike the Coal Mine Wasteland. Graduate University of Andalas.

Rosliani, R., Y. Hilman and N.Sumarni. 2004. Phosphate Fertilizer, Manure Lamb, and fungi inoculation AMF on the Growth and Yield of Cucumber Plants in Acid Soil. Vegetable Crops Research Institute Lembang, Bandung.

Sahera Nofyangtri, 2011. Effect of Drought Stress and Mycorrhizal Applications to MorfoPhysiological and Organic Materials Quality Forage Grasses and Legumes. Bogor Agricultural University graduate.

Simanungkalit, M.D.R., D.R. Suriadikarta, R. Saraswati, D. and W. Hartatik Setyorii. 2006. Fertilizer Organic and Biological Fertilizer (Organic Fertilizer and Biofertilizer). Indonesian Center for Agricultural Land Resources Research and Development, Agency for Agricultural Research and Development, Bogor.

Sukarmin and Goddess Fatria. 2011. Fungi Mycorrhizal Inoculation Techniques in Seed Soursop. Bulletin of Agricultural Engineering Vol.16, No. 2: 52-54.

Sumarsono, S. Anwar and S. Budiyanto. 2005. Role of Organic Fertilizer for the success of polyploid Grass Forage Crop Growth in Acid Soil and Copy. Research Report. Faculty of Animal Science, Diponegoro University, Semarang.

Sumarsono. 2006. Role of Forage Crops in Agriculture Environmental Interventions. Main Papers in Scientific Gathering Internal Faculty of Animal Husbandry, Diponegoro University, Semarang, March 29, 2006.

Syafna. 2009. Effects of Nitrogen Fertilization Inundation and cutting interval on the Growth and Production of Local Grass kumpai (Hymenachne amplexicaulis (Rudge) Nees.). Scientific Magazine spark Bandung. Issue May 2009. ISSN: 0854-8986. It: 97-100.

Vera Nania. 2007. Addition of AMF and Soil NPK Fertilizer on the Growth and Production Copy grass Chloris gayana Kunth. and Setaria splendida Stapf. Faculty of Animal Science, Bogor Agricultural University.

Widjajanto, DW, Honmura, T., Matsushita, K., and Miyauchi, N. 2001. Studies on the release of N from water hyacinth incorporated into soil-crop systems using $15 \mathrm{~N}$ - labeling techniques. Pak. J. Biol. Sci., 4 (9): 1075-1077. 